\title{
MULTIPLE-CRITERIA MODEL FOR OPTIMAL ANTI TANK GROUND MISSILE WEAPON SYSTEM PROCUREMENT
}

\author{
Dragan S. Pamučara, Slobodan R. Dimitrijevićb \\ a University of Defense in Belgrade, Military Academy, \\ Department of Logistics, Belgrade, Republic of Serbia, \\ e-mail: dragan.pamucar@va.mod.gov.rs, corresponding author, \\ ORCID iD: (Dhttps://orcid.org/0000-0001-8522-1942 \\ b Serbian Armed Forces, Peace Keeping Operations \\ Training Center, Base "South", Bujanovac, Republic of Serbia, \\ e-mail: slobodan.dimitrijevic@gmail.com, \\ ORCID iD: (Dhttps://orcid.org/0000-0002-3376-9030
}

DOI: 10.5937/vojtehg69-32117; https://doi.org/10.5937/vojtehg69-32117

FIELD: Mathematics, Logistics

ARTICLE TYPE: Original scientific paper

\begin{abstract}
:
Introduction: Anti Tank Ground Missiles (ATGMs) are one of the most efficient weapon systems to counter armored and mechanized units. Procurement of these weapons is imperative for armed forces of any country. Adequate evaluation and choice of an efficient ATGM system is a very important factor which affects operational capabilities of armed forces. The purpose of this paper is to present that multi criteria methods can be a useful tool for optimal procurement of ATGMs for armed forces.

Methods: The implementation of the TOPSIS (Technique for Order Preference by Similarity to Ideal Solution) and the MABAC (Multi Attributive Border Approximation Area Comparison) multi criteria methods will be proposed for decision makers to solve the problem of ATGM procurement. In this paper, four models of ATGMs will be proposed as possible solutions. These ATGMs will be presented as alternatives A1, A2, A3 and A4.

Results: The implementation of the methods in this paper has led to the conclusion that the alternative A2 has the highest value and therefore the best course of action for decision makers is to chose procurement of this model of ATGMs.

Conclusion: The conclusion is that the mathematical models of multi-criteria decision making presented in this paper unequivocally point to the alternative with the best characteristics, thus presenting extremely useful tools for decision makers.
\end{abstract}

Key words: TOPSIS, MABAC, weapon system procurement, multicriteria decision making. 


\section{Introduction}

Anti Tank Ground Missiles (ATGMs) represent one of the most efficient weapon systems present in armed forces globally. The primary purpose of these systems is anti armor defense, as well as partial anti air defense against low flying targets (helicopters and unmanned aerial vehicles). High hit probability and long range of engagement place these systems among the most deadly battlefield threats to armor units.

Regarding the fact that procurement of ATGMs represents one of the imperatives for equipping armed forces, the most optimal selection of ATGMs is one of the most challenging tasks for state decision makers, i.e. officials of the Defense Ministry.

Operational research as a basic management discipline based on mathematical formalism, with multi criteria methods as fundamentals for a decision making process, represents a solution for the ATGM procurement problem.

The objective of this paper is to present the capabilities of the multi criteria model as a comprehensive method for a decision making process where there is a need to select the most optimal solution.

In order to represent the complexity of the ATGM procurement problem, the first part of this paper will give a short history of ATGM development as well as the ATGM basic tactical and technical characteristics. The tactical and technical characteristics of ATGMs represent just a small portion of criteria included in the decision making process. All criteria which are in accordance with the adopted national defense doctrine must be included. Also, one of the crucial criteria is the cost-effectiveness criterion.

The ATGMs which will be described in this paper are fictional. Their specifications are approximate to real weapon systems in usage. The data for ATGMs are collected by accessing available reference documents primarily by the examination of official manufacturers' weapons specifications. As we already mentioned, the presented data will be partially changed in order to avoid similarity with actual weapon systems.

In the second part of this paper, the TOPSIS \& MABAC multi-criteria methods will be explained. These methods will be employed as a decision making tool for the ATGM procurement.

The motivation for selecting the TOPSIS and MABAC methods is justified by fact that these methods are comprehensive and represent one of the latest and most advanced scientific methods in the decision-making process. 


\section{ATGM development history and basic characteristics}

The ATGM development started at the end of WWII in Nazi Germany. Primarily, it was the Ruhrstahl X-7(Rotkäppchen -,Little Red Riding Hood"). The guidance method was manual, meaning that the operator was guiding a missile by the guidance panel with the joystick. After a missile is launched, the operator follows the missile and in the same time the operator follows the target (e.g. armored vehicle). With the command stick, the operator corrects the flight of the missile until it hits the target. The explained method is described as "Three-point guidance method" (operator's eye, missile, target) or, in Western literature, as MCLOS (Manual Command to Line of Sight). A typical example of this ATGM generation is the 9M14 Malyutka (Russian: Малютка; "Little one", NATO reporting name: AT-3 Sagger). The main characteristic of the first generation of ATGMs was long-lasting and complex training. The combat effectiveness of these ATGMs was approximately $25 \%$ during the ArabIsrael conflict in 1973.

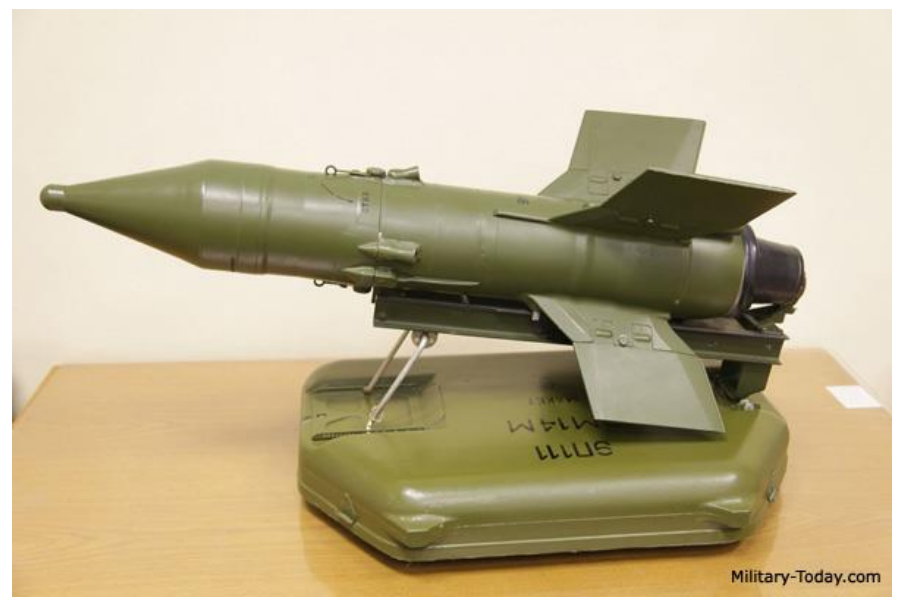

Figure 1 - 9M14 Malyutka (AT-3 Sagger), (Military-Today, 2021)

Puc. 1 - 9M14 «Малютка» (Military -Today, 2021)

Слика 1 - 9M14 „Маљутка” (Military -Today, 2021)

The two-point guidance method (operator's eye and target) is used in the second generation of ATGMs. After a missile is launched, this guidance method enables the operator to only constantly track a target with crosshairs (without following the missile flight), while the automatic system (the guidance block) processes and sends appropriate commands 
to the missile and therefore guides the missile to the target. The communication with the guidance block is conducted by wire or by radio waves. Typical examples of this generation ATGMs are: MILAN, 9K111 „FAGOT“(NATO reporting: AT-4 Spigot), BGM-71 TOW, and „BUMBAR“developed and produced in Serbia. The examples are given in Figure 2.

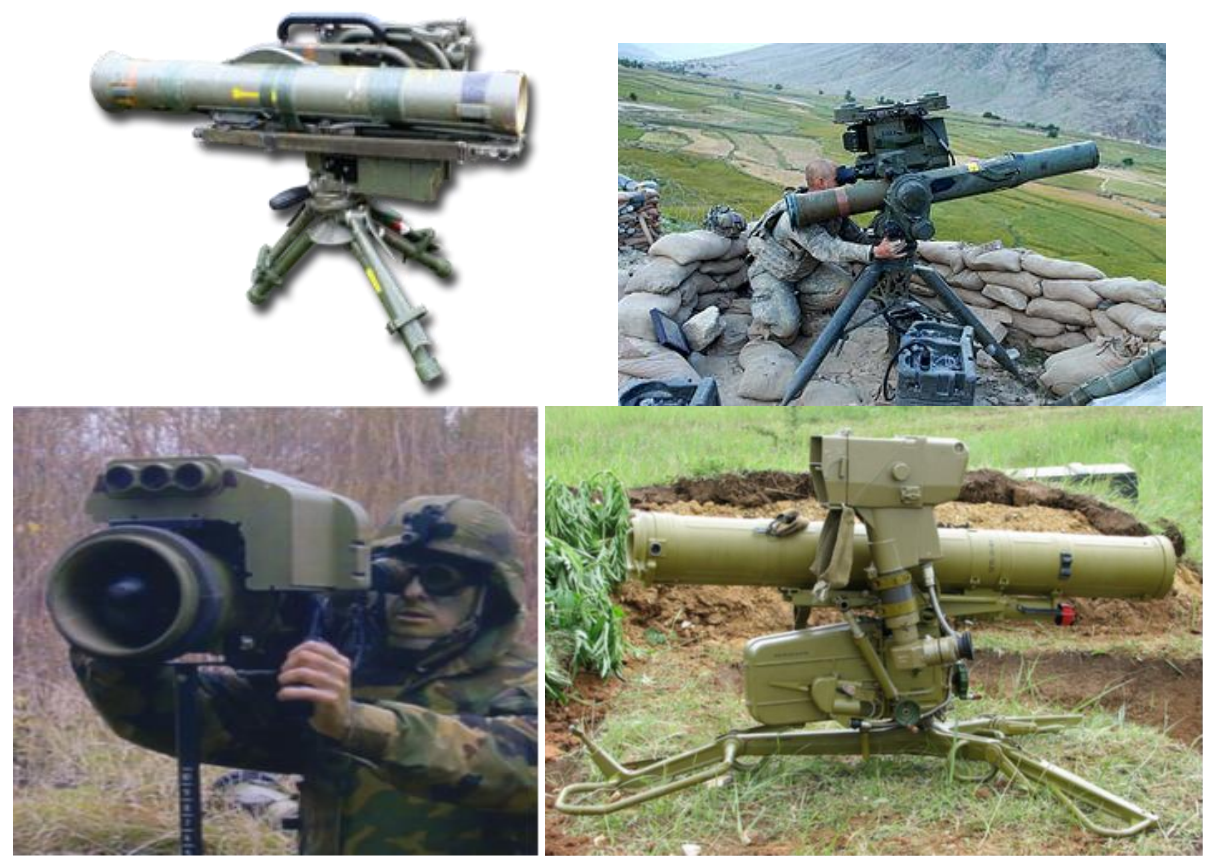

Figure 2 - Second generation ATGMs: MILAN, BGM-71 TOW (upper section); 9K111 "FAGOT" and „BUMBAR"(lower section)

PUc. 2 - ПТУР второго поколения: MILAN, BGM-71 TOW (верхний ряд); 9К111 "ФАГОТ» и "БУМБАР» (нижний ряд)

Слика 2 - ПОВР друге генерације: MILAN, BGM-71 TOW (горњи ред); „ФАГОТ” и „БУМБАР” (доњи ред)

The two-point guidance method is also employed on ATGMs guided by a focused beam (usually a laser beam) where a missile itself has an installed system which provides "riding a missile on a beam" and therefore there is no need for wire communication with the launching platform. The typical examples of this generation ATGMs are the 9M133 Kornet and the 9M119 Svir/Refleks (booth manufactured in Russia). The hit probability of the second generation of ATGMs is about $90 \%$. 
The third generation of ATGMs completely employs an automated guidance system. In Western literature, this system is designated as a "Fire and Forget" system. The operator selects a target and after launching the automatic system tracks the target and guides the missile to the target. The typical example of the third generation of ATGMs is the 9M133M Kornet-M. The automated system conducts the target tracking and focuses the laser beam to a target, which is used to guide a missile. This ATGM presents an improved version of the second generation of the $9 \mathrm{M} 133$ ATGM. The launching platform is capable of tracking two targets simultaneously. Besides anti-tank engagement, the system is intended for low altitude anti-aircraft defense (e.g. against unmanned aerial vehicles). The 9M133M Kornet-M ATGM is presented in Figure 3. The photo represents a Kornet $D$ variant which is capable of carrying 8 missiles (with additional 8 in reserve) on the GAZ 2975 all-terrain vehicle.

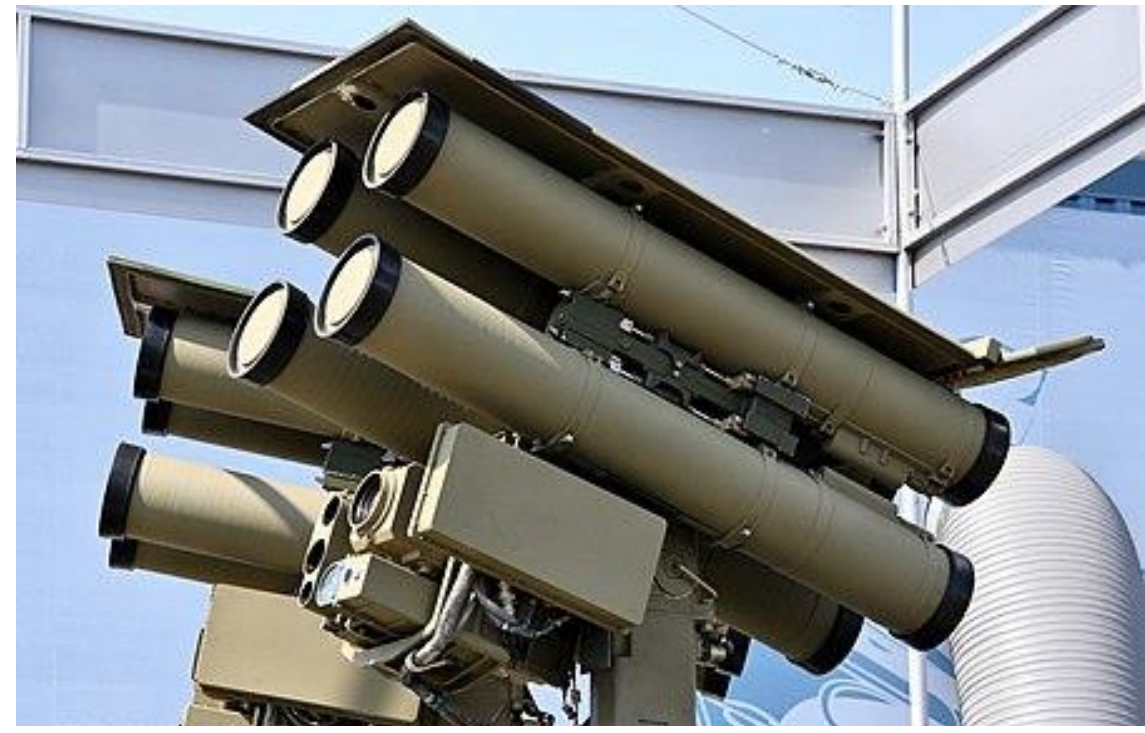

Figure 3-9M133M Kornet-M ATGM on the Kornet D platform Puc. 3 - ПТУР 9M133М «КОРНЕТ-М» на платформе «КОРНЕТ Д» Слика 3 - ПОВР 9M133М „КОРНЕТ - М” на „КОРНЕТ Д” платформи

The FGM-148 Javelin ATGM, manufactured by Raytheon Technologies, USA, represents one of the most sophisticated combat systems. One of the distinctive characteristics featured in this combat system is ability to attack the target from above where the upper armor is 
much thinner than the frontal armor, thus significantly improving target destruction probability.

This missile employs a section designated as a Seeker section. The seeker section consists of an imaging infrared system (I2R) and a contact fuse for warhead detonation. The I2R system provides the Fire and Forget capability. During the missile flight, the I2R system tracks a target and provides data to the electronic unit installed in the missile. Figures 4 and 5 show the target acquisition. After locating a target, the operator turns on the narrow field of view which engages track gates and crosshairs projected in intervals, indicating that the seeker is detecting target thermal reflection, or so called "target lock".

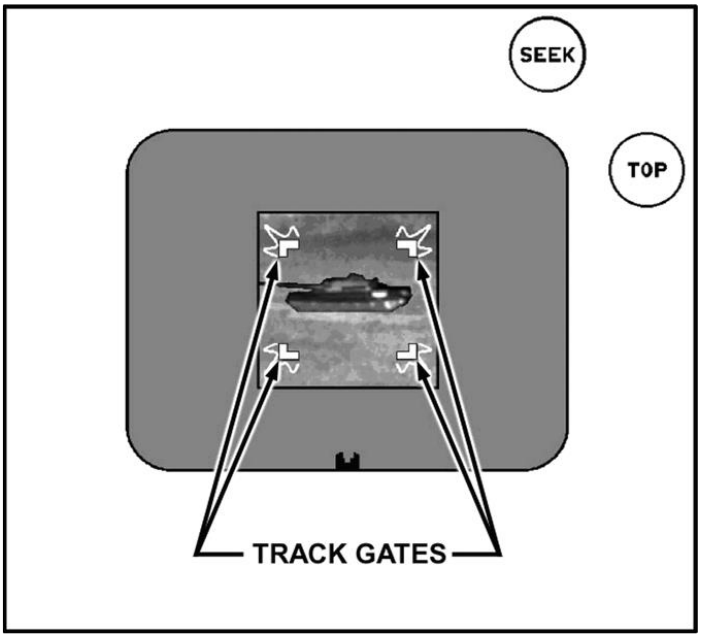

Figure 4 - Target thermal reflection detection - "Target lock"

Pис. 4 - Тепловое обнаружение ИК отражения- «Закрытая мишень»

Слика 4 - Детектовање инфрацрвеног одраза - „закључавање” циља

When the strongest thermal reflection is detected, the track gates and the crosshairs become solid, which is the indication that the target is "locked", i.e. the firing conditions are fulfilled and the system is ready to launch a missile (Figure 5). 


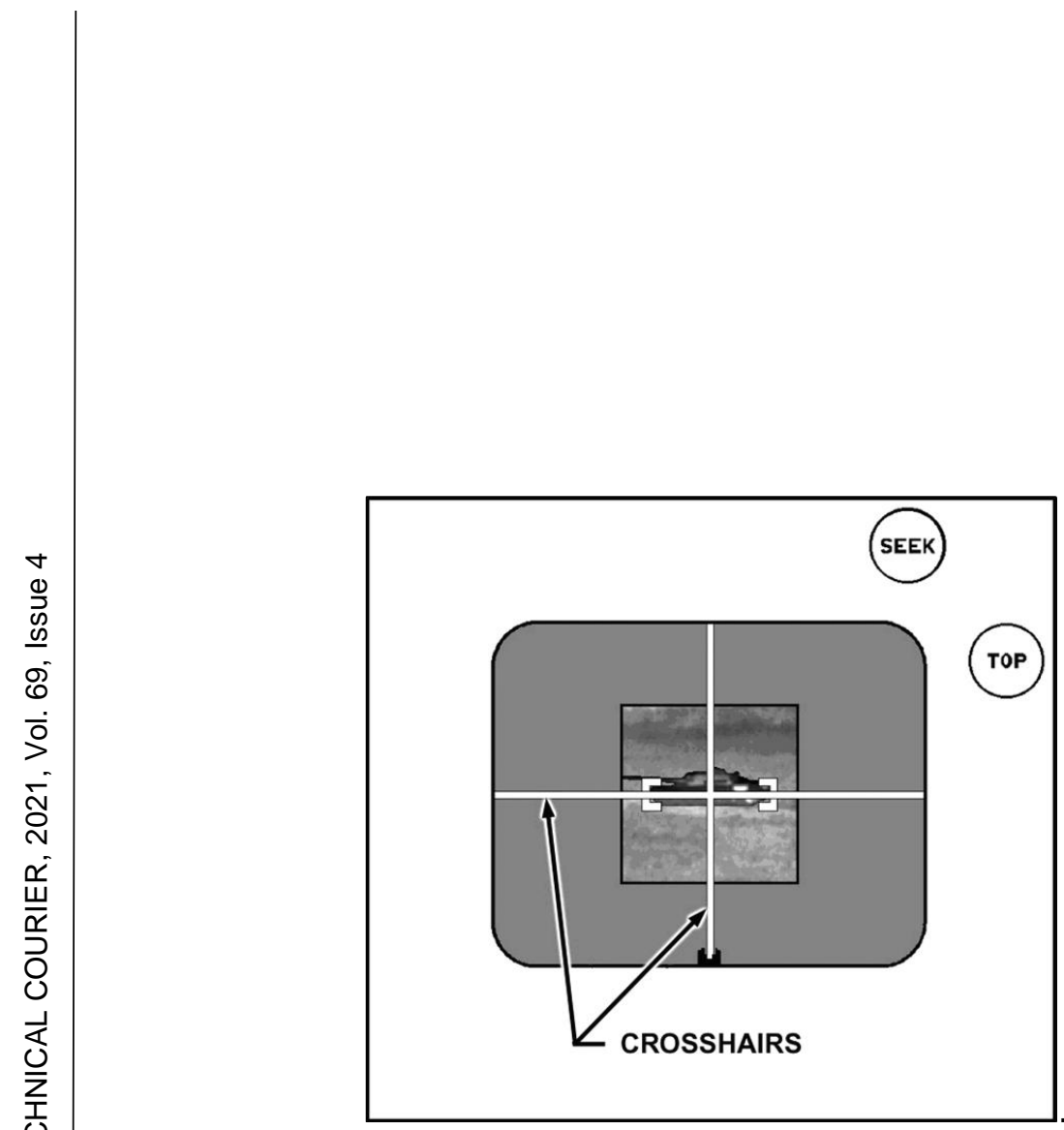

Figure 5 - Target "Locked" firing conditions fulfilled; system ready to launch a missile Рис. 5- Условия стрельбы по «Закрытой мишени» выполнены Слика 5 - Циљ „закључан” - услови за гађање испуњени

ATGMs are equipped with a warhead which destroys a target with an explosion cumulative effect ${ }^{1}$. A cumulative explosion effect represents focusing energy to a surface smaller than the outer surface of the explosive charge. Energy accumulation is created by a proper shape of the explosive charge. If the outer surface is shaped with a cone cavity (so called cumulative cavity), detonation products are focused in the center of the cavity. In that manner, energy accumulation is created on a smaller surface and therefore the effect of a larger magnitude is created.

The coating of the cumulative cavity also increases penetration capability. For the coating, the most used metal is copper, but steel can also be used as well as sintered metals. Figure 6 shows the formation of a cumulative beam while a cumulative beam formation radiograph is presented in Figure 7.

${ }^{1}$ In Western literature, the term shaped-charge is used. 


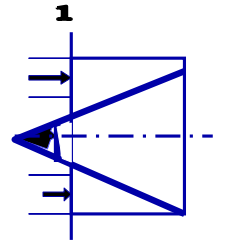

a

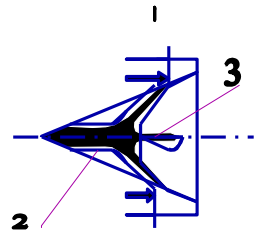

b_

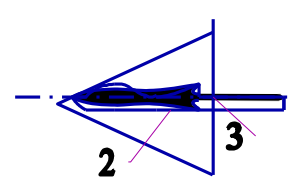

C

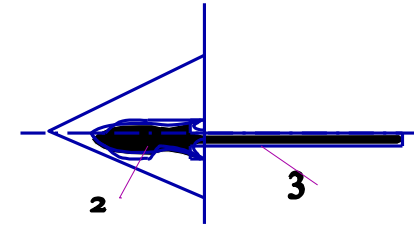

d

Figure 6 - Forming of a cumulative beam (1 - detonation wave; 2 - secondary beam; 3 primary beam)

Puс. 6 - Формирование кумулятивного снаряда (1 - детонационная волна; 2 вторичная струя; 3 - первичная струя)

Слика 6 - Формирање кумулативног млаза (1 - детонациони талас; 2 секундарни млаз; 3 - примарни млаз)

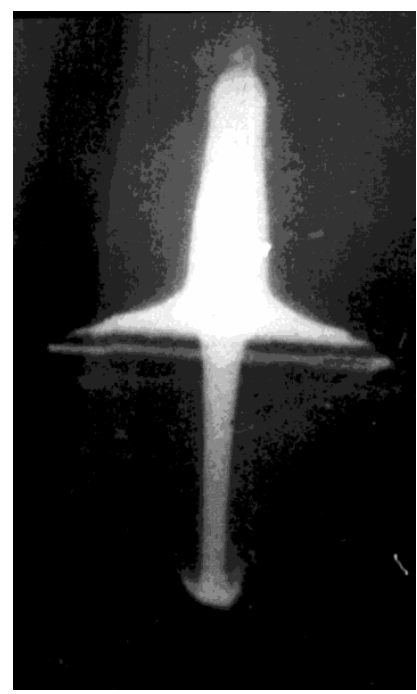

Figure 7 - Cumulative beam formation radiograph

Puc. 7- Рентгенограмма кумулятивного фрормирования струи

Слика 7- Рендгенографоки снимак кумулативног млаза у формирању

Modern ATGMs employ a so-called tandem-cumulative warhead $^{2}$ which is capable of forming two cumulative beams following each other. These beams are formed by two separated cumulative cavities. The purpose of the primary beam is to activate Explosive Reactive Armor

2 In Western literature, the term tandem-charge is used. 
$(E R A)^{3}$, and then the secondary beam penetrates the main armor. Modern third generation ATGMs penetrate more than $1,300 \mathrm{~mm}$ of homogenous armor behind ERA.

One of important characteristics of ATGMs is missile velocity. ATGM velocity is usually measured in meters per second $(\mathrm{m} / \mathrm{s})$ and it is ranged from $120 \mathrm{~m} / \mathrm{s}$ (First generation ATGM e.g. 9M14 Malyutka) up to $300 \mathrm{~m} / \mathrm{s}$ (Third generation ATGM e.g. ATGM 9M133M Kornet-M). It is evident that missile velocity is an important characteristic considering battlefield multiple targets engagement. From the previous example, it can be noticed that the third generation of ATGMs has the velocity almost twice as high as that of the first generation. Let us have an example when the operator locates two targets at a range of 2400 meters. For the guidance of the first generation of ATGMs, the operator needs approximately 20 seconds. For the guidance of the third generation of ATGMs, the operator needs approximately 8 seconds. This means that the operator armed with a third generation ATGM has enough time to destroy two targets, unlike the operator armed with a first generation ATGM.

The ATGM range of engagement is also an important characteristic. The ATGM range of engagement is form 3000 meters for the first generation ATGMs (e.g. 9M14 Malyutka) up to 8000 meters for the third generation ATGMs (e.g. 9M133M Kornet-M).

Regarding ATGM procurement for armed forces, the price of ATGMs is a factor which must be considered in conjunction with economic capabilities of the armed forces in question. Also, the ATGM weight must be considered in conjunction with armed forces transportation capabilities, as well as with the mobility of units armed with ATGMs.

In modern armed conflicts, electronic warfare (EW) is employed through system jamming, so electronic counter-countermeasures (ECCM) must be implemented, which for ATGMs can be expressed as jamming resistance. Besides jamming resistance, reliability is demanded for weapon systems.

Based on the previously mentioned ATGM development history and the presented tactical \& technical characteristics, the following criteria should be taken into account when procuring ATGMs:

- Engagement range,

- Hit probability,

- Weight,

- Price,

${ }^{3}$ Explosive Reactive Armor consists of explosive plates whose purpose is to disrupt a cumulative beam thus preventing armor penetration. 
- Training simplicity,

- Reliability,

- Jamming resistance, and

- Missile velocity.

\section{Multiple-criteria decision process}

In the previous chapter, the problem of ATGM procurement for armed forces has been presented. Finding an optimal solution, i.e. the decision making process and the selection of the "best" alternative, is based on multiple criteria and on series of limitations. The concerned criteria can be, by their nature, very diverse, and expressed in different units of measurement, from currency followed by physical units of measurement to subjective assumptions measured by a scale formed for a problem in question. Therefore, a final, unique solution cannot be determined without the participation of a decision maker. A decision maker must decide on a particular solution. The solution adopted by the decision maker is designated as the best or the most preferred solution. The task of multiplecriteria decision process is to provide assistance to the decision maker to select the best solution in the given conditions. Therefore, efforts made for solving multiple-criteria problems are designated as a multiple-criteria decision analysis.

The problems of multi-criteria optimization are characterized by:

- Presence of multiple criteria (objective function, criteria function) for decision making,

- Presence of multiple alternatives (solutions) for the selection,

- Presence of a designing process or solution selection,

- Presence of conflicts between the criteria, which is the most common case in real life problems,

- Incomparable units of measurement for different criteria, and

- Selection process of one final solution, which can be presented as a design of an action (alternative), or a selection of one particular action from the previously defined convolution of final actions.

There are many multiple-criteria decision process methods which have common aspects. The characteristic terms which occur in these methods are:

- Alternatives - represent selections of different actions which are available for a decision maker. The convolution of alternatives 
implies limited convolution, ranging from a few to a few hundreds. It is assumed that alternatives are verified, prioritized and in some cases ranked.

- Multiple attributes - different designations of attributes are "objectives" or "decision criteria" and represent different dimensions for which alternatives can be observed.

- Criteria conflict - different criteria represent different dimensions which can be in conflict.

- Incomparable units of measurement - different criteria can be linked with different units of measurement.

- Decision magnitude - most methods of the multiple-criteria decision process demand assignment of the weight criteria in accordance with their importance. Usually, these weights are normalized so that their sum equals one.

- Decision matrix - the multiple-criteria decision process can be represented in the form of a matrix. The decision matrix $(m x n)$ is a matrix in which the element $a_{i j}$ represents the characteristics of the alternative $A_{i}$ where $(i=1,2, \ldots, m)$, when the alternative $A_{i}$ is valued in accordance with the decision criteria $C_{j}(j=1,2, \ldots, n)$. Also, it is presumed that the decision maker has assigned the weight criterion $w_{j}(j=1,2, \ldots, n)$.

Multiple-criteria decision methods are employed in multiple disciplines and can be used in problem solving for any decision making process with multiple criteria. We well cite only a fraction of areas in which multiple criteria decision methods are employed:

- application in cargo distribution companies (Adar\& Delice, 2019)

- healthcare waste treatment technology selection (Adar\& Delice, 2020)

- menu evaluation (Arsić et al, 2019)

- decision making: applications in management and engineering (Božanić et al, 2020b)

- evaluating sustainable transportation systems (Muhammad et al, 2021)

- sustainable city logistics planning (Alosta et al, 2021) 
- evaluation of the performance of deposit banks (Ayçin \& Orçun, 2019)

- supplier selection (case study in pharmaceutical supplying in Libya) (Badi \& Ballem, 2018)

- efficiency of the social media (Bobar et al, 2020)

- supporting decision making in the army (Božanić et al, 2020a)

- evaluating locations for river crossing (Božanić \& Pamučar, 2010)

- ranking potential locations for preparing laying-up positions (Božanić et al, 2016a)

- selection of the location for construction, reconstruction and repair of flood defense facilities (Božanić et al, 2019a)

- selection of a location for the construction of a single-span bailey bridge (Božanić et al, 2019b)

- proposal for an optimal location of emergency operation centers (Di Matteo et al, 2016)

- support a decision making process of force deployment in a defense operation (Božanić et al, 2016b)

- support a decision making process of force deployment in a defense operation (Pamučar et al, 2016)

- selecting a location for wind farms (Gigović et al, 2017)

- selection of the railroad container terminal (Milosavljević et al, 2018)

- selection of transport and handling resources in logistics centers (Pamučar \& Ćirović, 2015)

- optimal off-road vehicle selection for passenger transportation (Pamučar \& Savin, 2020)

- sustainable selection of a location for the development of a multimodal logistics centre (Pamucar et al, 2018b)

- evaluating the work of advisors in the transport of hazardous goods (Pamučar et al, 2019)

- evaluation of level crossings (Pamučar et al, 2018a)

- selecting an airport ground access mode (Pamucar et al, 2020)

- survey on military operations of the fuzzy set theory and its applications (Deveci et al, 2020a) 
- comparison of two fuzzy multi criteria decision methods for selecting a potential airport location (Belbag et al, 2013)

- comparative analysis of fuzzy multi-criteria decision making for selecting a location for a textile plant in Turkey (Demirel et al, 2016)

- wind farms site selection (Deveci et al, 2020b) and (Deveci et al, 2021).

\section{Description of multiple-criteria decision methods used} in the decision making process for the problem in question

The methods of multiple-criteria decision making which will be used for finding the best solution are the TOPSIS и MABAC methods:

The TOPSIS (Technique for Order Preference by Similarity to Ideal Solution) method was developed by Hwang and Joon. This method implies ranking alternatives by multiple criteria based on the comparison of distances from the ideal solution and the negative ideal solution. The ideal solution minimizes the cost based criteria and maximizes the benefit type criteria, while for the negative ideal solution the opposite rule is implied.

The TOPSIS consists of six steps. Prior to the presentation of these steps, the terms to be used will be defined. In this method, the decision matrix $R$ is used, where every alternative is matched by one row and every column is matched by one criterion. The element $r_{g}$ represents the alternative performance $A_{i}$ related to the criterion $C_{j}$. For $m$ criteria $\left(C_{1}, C_{2} \ldots, C_{m}\right)$ and $n$ alternatives $\left(A_{1}, A_{2} \ldots, A_{n}\right)$, the matrix $R$ has the following form:

$$
R=\underset{A_{1}}{A_{2}} \begin{gathered}
A_{2} \\
A_{n}
\end{gathered}\left[\begin{array}{cccc}
r_{11} & r_{12} & \ldots & r_{1 m} \\
r_{21} & r_{22} & \ldots & r_{2 m} \\
& \ldots \ldots & \ldots & \\
r_{n 1} & r_{n 2} & \ldots & r_{m n}
\end{array}\right]
$$

and the values $\left(w_{1}, w_{2} \ldots, w_{m}\right)$ represent the weight values of the criteria. The weight of the criteria must be in compliance with the condition $\sum_{i=1}^{n} w_{i}$.

Step 1 Decision matrix values normalization. In the majority of multiple-criteria decision methods, the first step is decision matrix elements normalization in order to get a matrix in which all elements are 
un-dimensional values. In the TOPSIS method, vector normalization is applied, represented by expressions (2.1) and (2.2).

$x_{i j}=\frac{r_{i j}}{\sqrt{\sum_{i=1}^{n} r_{i j}^{2}}}$, for the "benefit" type criteria

After normalization implementation, the $X$ matrix is obtained in which all elements are normalized and are in the interval $[0,1]$.

$X=\frac{A_{1}}{A_{2}} \underset{A_{n}}{A_{n}}\left[\begin{array}{llll}x_{11} & x_{12} & \ldots & x_{1 m} \\ x_{21} & x_{22} & \ldots & x_{2 m} \\ x_{n 1} & x_{n 2} & \ldots & x_{m n}\end{array}\right]$

Step 2 Multiplication of the $X$ matrix normalized values with the weight criteria coefficients.

$v_{i j}=x_{i j} \cdot w_{j} ; j=1,2 \ldots, m$

With relation (2.3), the elements of the weight normalized matrix $V=$ $\left(v_{g}\right)$, are obtained, where every $v_{g}$ is a product of the normalized alternative performance and the appropriate criterion coefficient.

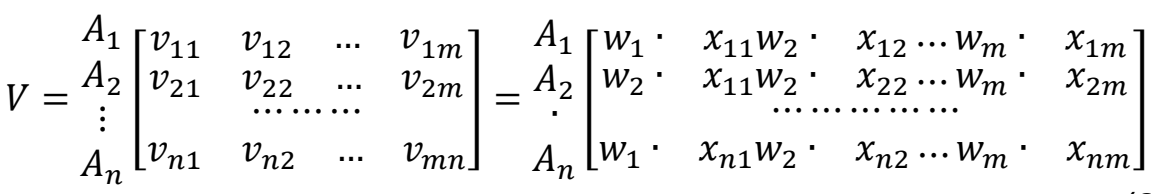

Step 3. Determination of ideal solutions. The ideal solution $A^{*}$ and the negative ideal solution are obtained by the following relations:

$\left.A^{*}=\left\{\left(\max v_{i j} \mid j \in G\right),\left(\min v_{g} \mid j \in G\right), i=1, \ldots, n\right\}=\left\{v_{1}^{*}, v_{2}^{*}, \ldots, v_{m}^{*}\right\}\right)(2.5)$

$A^{\prime \prime}=\left\{\left(\min v_{i j} \mid j \in G\right),\left(\max v_{g} \mid j \in G\right), i=1, \ldots, n\right\}=\left\{v_{1}^{-}, v_{2}^{-}, \ldots, v_{m}^{-}\right\}(2.6)$

where:

$G=\{j=1,2, \ldots$ m|japertaintocriteriawhicharemaximized $\}$

$G^{\prime}=\{j=1,2, \ldots$ m|japertaintocriteriawhichareminimized $\}$ 
The best alternatives are those which have the biggest $v_{g}$ relative to the criteria which are maximized and the smallest $v_{g}$ relative to the criteria which are minimized. $A^{*}$ indicates the best alternative (the ideal solution), and, using the same logic, $A^{\prime \prime}$ indicates the negative ideal solution.

Step 4 Determination of alternative distances from the ideal solution. In this step, using the following relations:

$$
\begin{aligned}
& S_{i}^{*}=\sum_{j=1}^{m}\left(v_{i j}-v_{j}^{*}\right)^{2}, i=1, \ldots, n \\
& S_{i}^{-}=\sum_{j=1}^{m}\left(v_{i j}-v_{j}^{-}\right)^{2}, i=1, \ldots, n
\end{aligned}
$$

$n$ dimensional Euclid distances are calculated of all alternative distances from the ideal solution and from the negative ideal solution.

Step 5 Determination of relative alternatives proximity to the ideal solution. For each alternative, relative distance is determined:

$$
Q_{i}^{*}=\frac{S_{i}^{-}}{S_{i}^{*}-S_{i}^{-}}, \quad i=1, \ldots, n
$$

where $0 \leq Q_{i}^{*} \leq 1$. The alternative $A_{i}$ is closer to the ideal solution if $Q_{i}^{*}$ is closer to the value of 1 , or, which is the same, if $S_{i}^{*}$ is closer to the value of 0 .

Step 6 Ranking of alternatives. The alternatives are ranked by the descending values $Q_{i}^{*}$. The best alternative is the alternative with the highest $Q_{i}^{*}$ value and vice versa.

The MABAC (Multi-Attributive Border Approximation area Comparison) represents one of recent date methods. The MABAC method was developed by Dragan Pamucar, PhD, University of Defence in Belgrade, Military Academy, Department of Logistics. Up to this date, this method has found wide application and modifications in multiple-criteria problem solving. The MABAC method basic setting is to define every criterion function distance from the border approximate area. The MABAC method consists of 6 steps: 
Step 1: Base matrix forming(X). In the first step, the evaluation of $m$ alternatives per $n$ criteria is performed. The alternatives are presented by vectors $A=\left(x_{i j}, x_{i 2}, \ldots, x_{m}\right)$ where the value $x_{g}$ is the value of the $i$ alternative per the $i$ criterion $(i=1,2, \ldots, m ; j=1,2, \ldots, n)$.

$$
\begin{aligned}
& \begin{array}{llll}
C_{1} & C_{2} & \ldots & C_{n}
\end{array}
\end{aligned}
$$

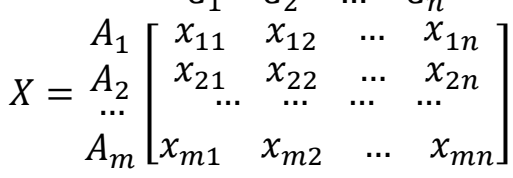

and where $m$ represents an alternative number while $n$ is the total number of criteria.

Step 2 Elements normalization of the base matrix $x$.

$$
\begin{aligned}
& \begin{array}{lllll}
C_{1} & C_{2} & \ldots & C_{n}
\end{array}
\end{aligned}
$$

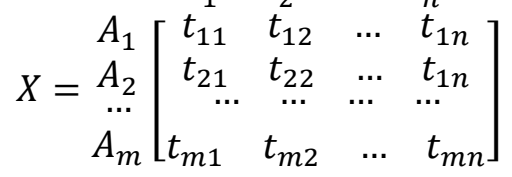

The elements of the normalized matrix $N$ are determined by the expression:

a) For the "benefit" type criteria (higher value desired)

$$
t_{g}=\frac{x_{g}-x_{i}^{-}}{x_{i}^{+}-x_{i}^{+}}
$$

b) For the "cost" type criteria (lower value desired)

$$
t_{g}=\frac{x_{i j}-x_{i}^{+}}{x_{i}^{-}-x_{i}^{+}}
$$

where $x_{i j}, x_{i}^{+}$and $x_{i}^{-}$represent the elements of the base matrix $(X)$, where $x_{i}^{+}$and $x_{i}^{-}$are defined as:

$x_{i}^{+}=\max \left(x_{1}, x_{2}, \ldots, x_{m}\right)$ and represents the maximum values of $\mathrm{a}$ considered criterion per alternatives. 
$x_{i}^{+}=\min \left(x_{1}, x_{2}, \ldots, x_{m}\right)$ and represents the minimum values of a considered criterion per alternatives.

Step 3 Aggravated matrix $(V)$ elements calculation. The elements of the aggravated matrix $(V)$ are calculated by expression (2.14):

$$
v_{g}=w_{i} \cdot t_{g}+w_{i}
$$

where $\left(t_{g}\right)$ represents the elements of the normalized matrix $(N), w_{i}$, represents weight criteria coefficients. By the application of expression (2.14), the aggravated matrix $(V)$ is obtained:

$$
V=\left[\begin{array}{cccc}
v_{11} & v_{12} & \ldots & v_{1 n} \\
v_{21} & v_{22} & \ldots & v_{2 n} \\
\ldots & \ldots & \ldots & \ldots \\
v_{m 1} & v_{m 2} & \ldots & v_{m n}
\end{array}\right]=\left[\begin{array}{cccc}
w_{1} \cdot t_{11}+w_{1} & w_{2} \cdot t_{12}+w_{2} & \ldots & w_{n} \cdot t_{1 n}+w_{n} \\
w_{1} \cdot t_{21}+w_{1} & w_{2} \cdot t_{22}+w_{2} & \ldots & w_{n} \cdot t_{2 n}+w_{n} \\
\ldots & \ldots \\
w_{1} \cdot t_{m 1}+w_{1} & w_{2} \cdot t_{m 2}+w_{2} & \ldots & w_{n} \cdot t_{m n}+w_{n}
\end{array}\right]
$$

where $n$ represents the total number of criteria and $m$ represents the total number of alternatives.

Step 4 Determination of the border approximate area $(G)$. The border approximate area (BAA) is determinated by expression (2.15):

$g=\left(\prod_{j=1}^{m} V_{i j}\right)^{\frac{1}{m}}$

where $v_{i j}$ represents the elements of the aggravated matrix $(V)$ and $m$ represents the total number of alternatives. After the calculation of the values $g_{i}$ per the border approximate area $(G)$ criterion, the matrix is formed with a format $n x 1$ ( $n$ represents the total number of criteria by which the selection of the offered alternatives is performed).

$$
\left.G=\begin{array}{cccc}
C_{1} & C_{2} & \ldots & C_{n} \\
g_{1} & g_{2} & \ldots & g_{n}
\end{array}\right]
$$

Step 5. Calculation of the distance matrix elements from the border approximate $\operatorname{area}(Q)$ 
$V=\left[\begin{array}{cccc}q_{11} & q_{12} & \ldots & q_{1 n} \\ q_{21} & q_{22} & \ldots & q_{2 n} \\ \ldots & \ldots & \ldots & \cdots \\ q_{m 1} & q_{m 2} & \ldots & q_{m n}\end{array}\right]$

The alternative distance from the border approximate area $\left(q_{i j}\right)$ is determinated as divergence of the elements of the aggravated matrix $(V)$ and the values of the border approximate $\operatorname{area}(G)$ :

$Q=V-G=\left[\begin{array}{cccc}v_{11} & v_{12} & \ldots & v_{1 n} \\ v_{21} & v_{22} & \ldots & v_{2 n} \\ \ldots & \ldots & \ldots & \ldots \\ v_{m 1} & v_{m 2} & \ldots & v_{m n}\end{array}\right]-\left[\begin{array}{llll}g_{1} & g_{2} & \ldots & g_{n}\end{array}\right]$

$V=\left[\begin{array}{cccc}v_{11}-g_{1} & v_{12}-g_{2} & \ldots & v_{1 n}-g_{n} \\ v_{21}-g_{1} & v_{22}-g_{2} & \ldots & v_{2 n}-g_{n} \\ \ldots & \ldots & \ldots & \ldots \\ v_{m 1}-g_{1} & v_{m 2}-g_{2} & \ldots & v_{m n}-g_{n}\end{array}\right]=\left[\begin{array}{cccc}q_{11} & q_{12} & \ldots & q_{1 n} \\ q_{21} & q_{22} & \ldots & q_{2 n} \\ \ldots & \ldots & \ldots & \ldots \\ q_{m 1} & q_{m 2} & \ldots & q_{m n}\end{array}\right]$

where $g_{i}$ represents the border approximate area for the criterion $C_{i}, v_{i j}$ represents the elements of the aggravated matrix $(V), n$ represents the number of criteria, and $m$ represents the number of alternatives.

The alternative $A_{i}$ can belong to the border approximate area $(G)$, the upper approximate area $\left(G^{+}\right)$or the lower approximate area $\left(G^{-}\right)$or $A_{i} \in$ $\left\{G \vee G^{+} \vee G^{-}\right\}$. The upper approximate area $\left(G^{+}\right)$represents the area where the alternative $\left(A^{+}\right)$can be found, while the lower approximate area $\left(G^{-}\right)$represents the area where the anti-ideal alternative $\left(A^{-}\right)$can be found (Figure 9). 


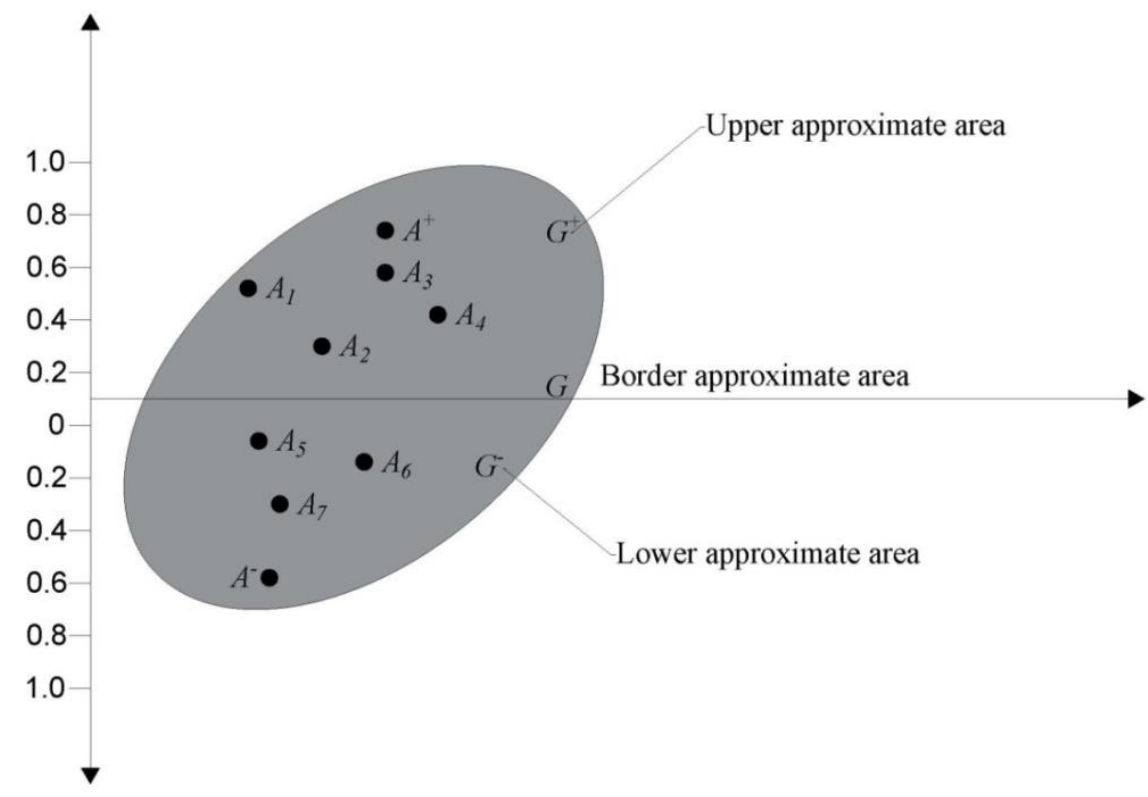

Figure 8 - Representation of the upper $\left(G^{+}\right)$, lower $\left(G^{-}\right)$and border $(G)$ approximate areas

Puc. 8 - Изображение верхней $\left(G^{+}\right)$, нижней (G ) и граничных (G) аппроксимативных областей

Слика 8- Приказ горње $\left(G^{+}\right)$, доње $\left(G^{-}\right)$и граничне $(G)$ апроксимативне области

Belonging of the alternative $A_{i}$ to the approximate area $\left(G, G^{+}, \operatorname{or} G^{-}\right)$ is determined by expression (2.20).

$$
A \in\left\{\begin{array}{c}
G^{+} i f q>g_{i} \\
G i f q_{i j}=g_{i} \\
G^{-} i f q_{i j}<g_{i}
\end{array}\right.
$$

In order to select the alternative $A_{i}$ as the best one from the congregation, it is required that this alternative, per most criteria, belongs to the upper approximate $\operatorname{area}\left(G^{+}\right)$. If, for example, the alternative $A_{i}$ per 5 criteria (from the total of 6 criteria) belongs to the upper approximate area, while by one criterion it belongs to the lower approximate area $\left(G^{-}\right)$, it means that this alternative is close or equal to the anti-ideal alternative per 5 criteria. If the values $q_{i j}>0$ or $q_{i j} \in G^{+}$, then the alternative $A_{i}$ is 
close or equal to the ideal alternative. The value $q_{i j}<0$ or $q_{i j} \in G^{-}$points out that the alternative $A_{i}$ is close or equal to the anti-ideal alternative.

Step 6 Ranking of alternatives. Calculation of the criteria function values per alternatives (2.21) is obtained as the sum of the alternatives distances from the border approximate areas $\left(q_{i}\right)$. By summing the matrix $Q$ by rows, the final criteria function of the alternatives values is obtained:

$$
S_{i}=\sum_{j=1}^{n} q_{i j}, j=1,2, \ldots, n,=1,2, \ldots, m
$$

where $n$ represents the total number of criteria and $m$ represents the number of alternatives.

Best alternative selection for ATGM procurement by the application of the TOPSIS method

In the chapter entitled "ATGM development history and basic characteristics" we have explained the basic ATGM characteristics. These characteristics are always listed in weapon systems manuals because of their tactical significance. That is why these characteristics will be used as the selection criteria.

To repeat, these criteria are as follows:

- K1: Engagement range in meters,

- K2: Hit probability (0-1),

- K3: Weight in kilograms,

- K4: Price in USD,

- K5: Training simplicity,

- K6: Reliability,

- K7: Jamming resistance, and

- K8: Missile velocity,

Under the assumption that we are selecting one ATGM from the proposed four ATGMs of different manufactures, represented as A1, A2, A3 and A4, the decision matrix for a ATGM selection is presented in Table 1.

The characteristics are similar to the characteristics of real weapon systems already in use. 
Table 1 - Base decision matrix

Таблица 1 - Базовая матрица решений

Табела 1 - Почетна матрица одлучивања

\begin{tabular}{|l|l|l|l|l|l|l|l|l|}
\hline & K1 & K2 & K3 & K4 & K5 & K6 & K7 & K8 \\
\hline A1 & 3000 & 0.35 & 28 & 1000 & Low & Middle & $\begin{array}{l}\text { Very } \\
\text { High }\end{array}$ & 115 \\
\hline A2 & 8000 & 0.95 & 30 & 5000 & $\begin{array}{l}\text { Very } \\
\text { High }\end{array}$ & $\begin{array}{l}\text { Very } \\
\text { High }\end{array}$ & $\begin{array}{l}\text { Very } \\
\text { High }\end{array}$ & 300 \\
\hline A3 & 2500 & 0.88 & 22 & 3000 & High & Middle & High & 186 \\
\hline A4 & 3500 & 0.89 & 25 & 4500 & High & Middle & High & 200 \\
\hline CRITERIA & $\max$ & $\max$ & $\min$ & $\min$ & $\max$ & max & max & max \\
\hline
\end{tabular}

In the given table, we can notice that, for the criteria $\kappa 1, \kappa 2, \kappa 5, \kappa 6$, $\mathrm{K} 7$ and $\mathrm{K} 8$, the most desirable values are the highest ones (max), while for the criteria $\mathrm{K} 3$ and $\mathrm{K} 4$ (weight and price, respectively), the most desirable are the lowest values (min).

Consider that the criteria $\mathrm{K} 5, \mathrm{~K} 6$ and $\mathrm{K} 7$ are represented by quality grades; quantification by quality grades will be performed by the application of the scale presented in Table 2.

Table 2 - Quality criteria $K 5, K 6$ and $K 7$ quantification scale

Таблица 2 - Шкала качественных и количественных критериев К5, К6 и К7

Табела 2 - Скала за квантифрикацију квалитативних критеријума К5, К6 и К7

\begin{tabular}{|l|l|l|l|l|l|}
\hline Estimation & Very High & High & Middle & Low & Very low \\
\hline Grade & 9 & 7 & 5 & 3 & 1 \\
\hline
\end{tabular}

By the application of the quantitative values from Table 2, the quantified matrix is presented.

Table 3- Quantified decision matrix

Таблица 3 - Матрица количественных решений

Табела 3 - Квантифрикована матрица одлучивања

\begin{tabular}{|l|l|l|l|l|l|l|l|l|}
\hline & K1 & K2 & К3 & K4 & К5 & К6 & К7 & К8 \\
\hline A1 & 3000 & 0.35 & 28 & 1.0 & 3 & 5 & 9 & 115 \\
\hline A2 & 8000 & 0.95 & 30 & 5.0 & 9 & 9 & 9 & 300 \\
\hline A3 & 2500 & 0.88 & 22 & 3.0 & 7 & 5 & 7 & 186 \\
\hline
\end{tabular}




\begin{tabular}{|l|l|l|l|l|l|l|l|l|}
\hline & К1 & К2 & К3 & К4 & К5 & К6 & К7 & К8 \\
\hline A4 & 3500 & 0.89 & 25 & 4.5 & 7 & 5 & 7 & 200 \\
\hline$\sqrt{\sum_{i=1}^{4} r_{i j}^{2}}$ & 9565.56 & 1.61 & 52.85 & 7.43 & 13.71 & 12.49 & 16.12 & 421.69 \\
\hline
\end{tabular}

Applying the expression $x_{i j}=\frac{r_{i j}}{\sqrt{\sum_{i=1}^{n} r_{i j}^{2}}}$, we will normalize the elements of the base decision and we will obtain the matrix presented in Table 4.

Table 4 - Normalized decision matrix

Таблица 4 - Нормализованная матрица решений

Табела 4 - Нормализована матрица одлучивања

\begin{tabular}{|l|l|l|l|l|l|l|l|l|}
\hline & K1 & K2 & K3 & K4 & K5 & K6 & K7 & K8 \\
\hline A1 & 0.314 & 0.217 & 0.470 & 0.865 & 0.219 & 0.400 & 0.558 & 0.273 \\
\hline A2 & 0.836 & 0.590 & 0.432 & 0.327 & 0.656 & 0.721 & 0.558 & 0.711 \\
\hline A3 & 0.261 & 0.547 & 0.584 & 0.596 & 0.511 & 0.400 & 0.434 & 0.441 \\
\hline A4 & 0.366 & 0.553 & 0.527 & 0.395 & 0.511 & 0.400 & 0.434 & 0.474 \\
\hline
\end{tabular}

In order to obtain the aggravated normalized value matrix, it is necessary to multiply the values form Table 4 with the weight coefficients.

Let us assume that, in our example, an authority expert team, formed to procure ATGMs for the Armed Forces of one particular state, has reached the decision that some criteria have advantage over the others. In such a case, we can rank the before mentioned criteria as follows:

I. Hit probability,

II. Engagement range in meters,

III. Weight,

IV. Price,

V. Reliability,

VI. Training simplicity,

VII. Missile velocity, and

VIII. Jamming resistance.

Based on this requirement, we can assign numerical values, in the range from the minimum value of 0.062 for the criteria with the least importance to the value of 0.246 for the criteria with the highest 
importance. Two criteria - hit probability and engagement range - have the highest values because of their tactical significance.

\begin{tabular}{|l|l|l|}
\hline Engagement range in meters & w1 & 0.242 \\
\hline Hit probability & w2 & 0.246 \\
\hline Price & w3 & 0.116 \\
\hline Weight & w4 & 0.119 \\
\hline Missile velocity & w5 & 0.063 \\
\hline Jamming resistance & w6 & 0.062 \\
\hline Training simplicity & w7 & 0.072 \\
\hline Reliability & w8 & 0.080 \\
\hline
\end{tabular}

By the application of the expression $v_{i j}=x_{i j} \cdot w_{j} ; j=1,2 \ldots, m$ the aggravated normalized matrix is obtained and presented in Table 5.

Table 5 - Aggravated normalized matrix

Таблица 5 - Усложненная нормализованная матрица Табела 5 - Отежана нормализована матрица

\begin{tabular}{|l|l|l|l|l|l|l|l|l|}
\hline & K1 & K2 & K3 & K4 & K5 & K6 & K7 & K8 \\
\hline A1 & 0.0759 & 0.0535 & 0.0545 & 0.1030 & 0.0138 & 0.0248 & 0.040 & 0.022 \\
\hline A2 & 0.2024 & 0.1452 & 0.0502 & 0.0390 & 0.0414 & 0.0447 & 0.040 & 0.057 \\
\hline A3 & 0.0632 & 0.1345 & 0.0677 & 0.0710 & 0.0322 & 0.0248 & 0.031 & 0.035 \\
\hline A4 & 0.0885 & 0.1360 & 0.0611 & 0.0470 & 0.0322 & 0.0248 & 0.031 & 0.038 \\
\hline
\end{tabular}

Step 3 Determining the ideal solutions. The ideal solution $A^{*}$ and the negative ideal solution $A^{-}$are determined by applying the expressions:

$$
\begin{aligned}
& \left.A^{*}=\left\{\left(\max v_{i j} \mid j \in G\right),\left(\min v_{g} \mid j \in G\right), i=1, \ldots, n\right\}=\left\{v_{1}^{*}, v_{2}^{*}, \ldots, v_{m}^{*}\right\}\right) \\
& A^{\prime \prime}=\left\{\left(\min v_{i j} \mid j \in G\right),\left(\max v_{g} \mid j \in G\right), i=1, \ldots, n\right\}=\left\{v_{1}^{-}, v_{2}^{-}, \ldots, v_{m}^{-}\right\}
\end{aligned}
$$

Since the ideal alternatives are those with the highest $v_{i j}$ related to the criteria which are maximized and with the lowest $v_{i j}$ related to the criteria which are maximized, based on Table 5, we will obtain the ideal solution: 


$$
\left(A^{*}\right) \rightarrow A^{*}=\{0.2024,0.1452,0.0502,0.0390,0.0414,0.0447,0.0402,0.0569\}
$$

Step 5 Determining the relative distance of the alternatives to the ideal solution. By the application of the expression: $Q_{i}^{*}=\frac{s_{i}^{-}}{S_{i}^{*}-S_{i}^{-}}, i=1, \ldots, n$ relative distance is determined for each solution, Table 7.

Table 7 - Relative proximity of the alternatives $\left(Q_{i}^{*}\right)$ 
Таблица 7 - Относительная близость альтернатив $\left(Q_{i}^{*}\right)$ Табела 7 - Релативна близина алтернатива $\left(Q_{i}^{*}\right)$

\begin{tabular}{|l|l|l|}
\hline Alternatives & \multicolumn{1}{|c|}{$Q_{i}^{*}$} & RANK \\
\hline A1 & 0.1036 & 4 \\
\hline A2 & 1.0000 & 1 \\
\hline A3 & 0.3786 & 3 \\
\hline A4 & 0.4712 & 2 \\
\hline
\end{tabular}

Step 6 Alternative ranking. As it has already been mentioned, the alternatives are ranked by declining values $Q_{i}^{*}$. The best alternative is the alternative which has the highest value $Q_{i}^{*}$, i.e. in our example the alternative $A 2$. The alternative rank is presented in Table 7, i.e. $A 2 \rightarrow A 4 \rightarrow$ $A 3 \rightarrow A 1$.

\section{Best alternative selection for ATGM procurement by} the application of the MABAC method

The procurement of an ATGM will be examined, i.e. the selection of the best alternative, using the MABAC method of the multiple-criteria decision making process.

Step 1 Base decision matrix forming $(X)$. As in the previous example, we will examine four ATGMs. In Table 8, the characteristics of four ATMGs are presented. Table 8 also gives the base decision matrix.

Table 8 - Base decision matrix
Таблица 8 - Базовая матрица решений

Табела 8 - Почетна матрица одлучивања

\begin{tabular}{|c|c|c|c|c|c|c|c|c|}
\hline \multirow[b]{2}{*}{ Alternatives } & \multicolumn{8}{|c|}{ Criteria } \\
\hline & $\begin{array}{l}C 1 \\
(\max )\end{array}$ & $\begin{array}{l}C 2 \\
(\max )\end{array}$ & $\begin{array}{l}\text { C3 } \\
(\min )\end{array}$ & $\begin{array}{l}\text { C4 } \\
(\min )\end{array}$ & $\begin{array}{l}\text { C5 } \\
\text { (max) }\end{array}$ & $\begin{array}{l}\text { C6 } \\
(\max )\end{array}$ & $\begin{array}{l}C 7 \\
(\max )\end{array}$ & $\begin{array}{l}\text { C8 } \\
(\max )\end{array}$ \\
\hline $\mathrm{A} 1$ & 3000 & 0.350 & 28 & 1000 & B & $\mathrm{M}$ & VG & 115 \\
\hline $\mathrm{A} 2$ & 8000 & 0.950 & 30 & 5000 & VG & VG & VG & 300 \\
\hline A3 & 2500 & 0.880 & 22 & 3000 & $\mathrm{D}$ & $\mathrm{M}$ & $M$ & 186 \\
\hline A4 & 3500 & 0.890 & 25 & 4500 & $\mathrm{D}$ & M & $M$ & 200 \\
\hline w1 & 0.242 & 0.246 & 0.116 & 0.119 & 0.063 & 0.062 & 0.072 & 0.080 \\
\hline
\end{tabular}

For evaluating the alternatives according to the C5, C6 and C7 criteria, the Likert scale (Table 9) will be applied. 
Table 9 - Likert scale for evaluating alternatives

Таблица 9 - Шкала Лайкерта для оценки альтернатив

Табела 9 - Ликертова скала за евалуацију алтернатива

\begin{tabular}{|l|l|l|}
\hline $\mathrm{N}^{\circ}$ & Linguistic designation & Numerical value \\
\hline & Very Good (VG) & 5 \\
\hline & Good (G) & 4 \\
\hline & Middle (M) & 3 \\
\hline & Bad (B) & 2 \\
\hline & Very Bad (VB) & 1 \\
\hline
\end{tabular}

By the application of the Likert scale, the base decision matrix with numerical values is obtained.

Table 10 - Base decision matrix with numerical values

Таблица 10 - Базовая матрица решений

Табела 10 - Почетна матрица одлучивања

\begin{tabular}{|c|c|c|c|c|c|c|c|c|}
\hline \multirow[b]{2}{*}{ Alternatives } & \multicolumn{8}{|c|}{ Criteria } \\
\hline & $\begin{array}{l}\text { C1 } \\
\text { (max) }\end{array}$ & $\begin{array}{l}\text { C2 } \\
\text { (max) }\end{array}$ & $\begin{array}{l}\text { C3 } \\
\text { (min) }\end{array}$ & $\begin{array}{l}\text { C4 } \\
\text { (min) }\end{array}$ & $\begin{array}{l}\text { C5 } \\
\text { (max) }\end{array}$ & $\begin{array}{l}\text { C6 } \\
\text { (max) }\end{array}$ & $\begin{array}{l}C 7 \\
(\max )\end{array}$ & $\begin{array}{l}\text { C8 } \\
\text { (max) }\end{array}$ \\
\hline A1 & 3000 & 0.350 & 28 & 1000 & 2 & 3 & 5 & 115 \\
\hline $\mathrm{A} 2$ & 8000 & 0.950 & 30 & 5000 & 5 & 5 & 5 & 300 \\
\hline A3 & 2500 & 0.880 & 22 & 3000 & 4 & 3 & 4 & 186 \\
\hline A4 & 3500 & 0.890 & 25 & 4500 & 4 & 3 & 4 & 200 \\
\hline w1 & 0.242 & 0.246 & 0.116 & 0.119 & 0.063 & 0.062 & 0.072 & 0.080 \\
\hline
\end{tabular}

Step 2 Base matrix elements normalization $(X)$. After forming the base decision matrix $(X)$, Table 10, the normalization of the base matrix elements is facilitated.

In our example, the "benefit" type criteria (highest values desired) are $C 1, C 2, C 5, C 6, C 7$ and $C 8$; therefore, for calculating the normalized matrix $N$ elements, the following expression will be applied: 


$$
t_{g}=\frac{x_{g}-x_{i}^{-}}{x_{i}^{+}-x_{i}^{+}}
$$

For the "cost" type criteria (lowest criteria values desired), which in our example are C3 and C4, the following expression is applied for calculation:

$$
t_{g}=\frac{x_{i j}-x_{i}^{+}}{x_{i}^{-}-x_{i}^{+}}
$$

By the application of the previously given expressions, the normalized matrix $\mathrm{N}$ is obtained and presented in Table 11.

Table 11 - Normalized matrix $N$

Таблица 11 - Нормализованная матрица N

\begin{tabular}{|c|c|c|c|c|c|c|c|c|}
\hline \multirow{2}{*}{$\begin{array}{l}\text { Alterna- } \\
\text { tives }\end{array}$} & \multicolumn{8}{|c|}{ Criteria } \\
\hline & $C 1$ & $C 2$ & C3 & $C 4$ & C5 & C6 & $C 7$ & $C 8$ \\
\hline $\mathrm{A} 1$ & 0.091 & 0.000 & 0.250 & 1.000 & 0.000 & 0.000 & 1.000 & 0.000 \\
\hline $\mathrm{A} 2$ & 1.000 & 1.000 & 0.000 & 0.000 & 1.000 & 1.000 & 1.000 & 1.000 \\
\hline A3 & 0.000 & 0.883 & 1.000 & 0.500 & 0.667 & 0.000 & 0.000 & 0.384 \\
\hline A4 & 0.182 & 0.900 & 0.625 & 0.125 & 0.667 & 0.000 & 0.000 & 0.459 \\
\hline w1 & 0.242 & 0.246 & 0.116 & 0.119 & 0.063 & 0.062 & 0.072 & 0.080 \\
\hline
\end{tabular}

Табела 11 - Нормализована матрица N

3 The calculation of the aggravated matrix $V$ (Table 12) elements is performed by multiplying the weight coefficients, presented in the last row of the table. The weight coefficients are identical to those in the decisionmaking process when the TOPSIS method is used. Therefore, by the application of the expression

$$
v_{g}=w_{i} \cdot t_{g}+w_{i},
$$

the elements of the aggravated matrix $V$ are obtained and presented in Table 12. 
Table 12 - Aggravated normalized matrix $V$

Таблица 12 - Усложненная нормализованная матрица $V$

Табела 12 - Отежана нормализована матрица $V$

\begin{tabular}{|l|l|l|l|l|l|l|l|l|}
\hline \multirow{2}{*}{ Alternatives } & \multicolumn{2}{|l}{ Criteria } \\
\cline { 2 - 9 } & $C 1$ & $C 2$ & $C 3$ & $C 4$ & $C 5$ & $C 6$ & $C 7$ & $C 8$ \\
\hline A1 & 0.264 & 0.246 & 0.145 & 0.238 & 0.063 & 0.062 & 0.144 & 0.080 \\
\hline A2 & 0.484 & 0.492 & 0.116 & 0.119 & 0.126 & 0.124 & 0.144 & 0.160 \\
\hline A3 & 0.242 & 0.463 & 0.232 & 0.179 & 0.105 & 0.062 & 0.072 & 0.111 \\
\hline A4 & 0.286 & 0.467 & 0.189 & 0.134 & 0.105 & 0.062 & 0.072 & 0.117 \\
\hline
\end{tabular}

Step 4 Determination of the border approximate areas values $(G)$. By the application of geometric averaging for the values of the alternatives, with the expression

$g=\left(\prod_{j=1}^{m} V_{g}\right)^{1 / m}$

the border approximate areas matrix $(G)$ is obtained, Table 13.

Table 13 - Border Approximate Areas (BAA) matrix

Таблица 13 - Матрица граничных аппроксимативных областей (ГАО)

Табела 13 - Матрица граничних апроксимативних области (ГАО)

\begin{tabular}{|c|l|l|l|l|l|l|l|l|}
\hline \multirow{2}{*}{ BAA } & \multicolumn{6}{|l|}{ Criteria } \\
\cline { 2 - 9 } & $C 1$ & $C 2$ & $C 3$ & $C 4$ & $C 5$ & $C 6$ & $C 7$ & $C 8$ \\
\hline$g_{i}$ & 0.3067 & 0.4024 & 0.1647 & 0.1613 & 0.0967 & 0.0737 & 0.1018 & 0.1134 \\
\hline
\end{tabular}

Step 5 Calculation of the distance of alternatives (matrix elements) from the border approximate $\operatorname{area}(Q)$. The distance od the alternatives from the BAA (Table 14) is determined by the expression:

$$
Q=V-G=\left[\begin{array}{cccc}
v_{11} & v_{12} & \ldots & v_{1 n} \\
v_{21} & v_{22} & \ldots & v_{2 n} \\
\ldots & \ldots & \ldots & \ldots \\
v_{m 1} & v_{m 2} & \ldots & v_{m n}
\end{array}\right]-\left[\begin{array}{llll}
g_{1} & g_{2} & \ldots & g_{n}
\end{array}\right]
$$


as a reminder of the aggravated matrix $(V)$ elements, and the values from the border approximate area matrix $(G)$. By the application of the expression:

$$
V=\left[\begin{array}{cccc}
v_{11}-g_{1} & v_{12}-g_{2} & \ldots & v_{1 n}-g_{n} \\
v_{21}-g_{1} & v_{22}-g_{2} & \ldots & v_{2 n}-g_{n} \\
\ldots & \ldots & \ldots & \ldots \\
v_{m 1}-g_{1} & v_{m 2}-g_{2} & \ldots & v_{m n}-g_{n}
\end{array}\right]=\left[\begin{array}{cccc}
q_{11} & q_{12} & \ldots & q_{1 n} \\
q_{21} & q_{22} & \ldots & q_{2 n} \\
\ldots & \ldots & \ldots & \ldots \\
q_{m 1} & q_{m 2} & \ldots & q_{m n}
\end{array}\right]
$$

$q$ elements are obtained, in the matrix $(G)$ showing the distance of the alternatives from the border approximate area.

Table 14 - Matrix of the distances of alternatives from the $B A A(Q)$

Таблица 14 - Матрица расстояния альтернатив от ГАО (Q)

Табела 14 - Матрица удаљености алтернатива од ГАО $(Q)$

\begin{tabular}{|c|c|c|c|c|c|c|c|c|}
\hline \multirow{2}{*}{ Alternatives } & \multicolumn{8}{|c|}{ Criteria } \\
\cline { 2 - 9 } & $C 1$ & $C 2$ & $C 3$ & $C 4$ & $C 5$ & $C 6$ & $C 7$ & $C 8$ \\
\hline A1 & -0.0427 & -0.1564 & -0.0197 & 0.0767 & -0.0337 & -0.0117 & 0.0422 & -0.0334 \\
\hline A2 & 0.1773 & 0.0896 & -0.0487 & -0.0423 & 0.0293 & 0.0503 & 0.0422 & 0.0466 \\
\hline A3 & -0.0647 & 0.0609 & 0.0673 & 0.0172 & 0.0083 & -0.0117 & -0.0298 & -0.0027 \\
\hline A4 & -0.0207 & 0.0650 & 0.0238 & -0.0274 & 0.0083 & -0.0117 & -0.0298 & 0.0033 \\
\hline
\end{tabular}

Step 6 Alternative ranking. The criteria function values by alternatives are obtained by summing the elements from the matrix $Q$ by rows, by the application of the expression:

$S_{i}=\sum_{j=1}^{n} q_{i j}, j=1,2, \ldots, n, i=1,2, \ldots, m$

The values of the criteria functions and the final rank of the alternatives are presented in Table 15. 
Table 15 - Alternative ranking by the MABAC method

Таблица 15 - Альтернативное ранжирование по методу МАВАС

Табела 15 - Ранг алтернатива по методи МАBAC

\begin{tabular}{|l|l|l|}
\hline Alternatives & \multicolumn{1}{|c|}{$Q$} & RANK \\
\hline A1 & -0.1787 & $\mathbf{4}$ \\
\hline A2 & 0.3443 & $\mathbf{1}$ \\
\hline A3 & 0.0448 & $\mathbf{2}$ \\
\hline A4 & 0.0108 & $\mathbf{3}$ \\
\hline
\end{tabular}

Based on the obtained results, we can conclude that the alternative $A 2$ is first ranked, i.e. the alternatives are ranked as follows: $A 2 \rightarrow A 3 \rightarrow$ $A 4 \rightarrow A 1$.

\section{Conclusion}

By analyzing the data presented in Table 7(relative alternative proximity $\left(Q_{i}^{*}\right)$ by the application of the TOPSIS method) and the data presented in Table 15 (alternative ranking by the application of the MABAC method), we can observe that the alternative $A 2$ has the highest value and the alternative $A 1$ has the lowest value. The alternatives $A 3$ and $A 4$ have relatively close values. Based on the stated, we can conclude that both methods of multi-criteria decision making are pointing that the best alternative, therefore a decision for the best ATGM weapon system, is presented in the alternative A2. Both methods show that the selection of the alternative A1 would be a wrong decision for procurement. In the applied methods, the alternatives ranking of A3 and A4 are different, so a decision maker can optionally decide (for example to lower the expenses) to select the alternative A3.

The characteristics of the alternative $A 2$ are similar to the characteristics of the 9M133M Kornet-M ATGM, which represents one of the best, battle proven, weapon systems in world. We can conclude that the mathematical models of multi-criteria decision methods - which in our example unequivocally point to the alternative A2 - present an extremely helpful tool for decision makers.

The novelty of the method described in this paper is in the fact that a specific scientific method can be used for weapon system procurement for armed forces, therefore for gaining advancement in operational capabilities of armed forces. 
The intention of the authors is to implement this method in future studies especially in the area of military decision making. The focus will be on counter insurgency operations with adversary personified in multiple militant groups. In this scenario, friendly forces will be equipped with most advanced weapon systems such as armed unmanned air vehicles (drones and loitering munitions) and unmanned ground vehicles.

\section{References}

Adar, T. \& Delice, E.K. 2020. New integrated approaches based on MCHFLTS for healthcare waste treatment technology selection. Journal of Enterprise Information, 32(4), pp.688-711. Available at: https://doi.org/10.1108/JEIM-102018-0235.

Adar, T. \& Delice, E.K.2019. An Integrated MC-HFLTS\&MAIRCA Method and Application in Cargo Distribution Companies. International Journal of Supply and Operations Management, 6(3), pp.276-281. Available at: https://doi.org/10.22034/2019.3.7.

Alosta, A., Elmansuri, O. \& Badi, I. 2021. Resolving a location selection problem by means of an integrated AHP-RAFSI approach. Reports in Mechanical Engineering, 2(1), 135-142. https://doi.org/10.31181/rme200102135a.

Arsić, S., Pamučar, D., Suknović, M. \& Janošević, M. 2019. Menu evaluation based on rough MAIRCA and BW methods. Serbian Journal of Management, 14(1), pp.27-48. Available at: https://doi.org/10.5937/sjm14-18736.

Ayçin, E. \& Orçun, Ç. 2019. Evaluation of Performance of Deposit Banks by Entropy and MAIRCA Methods. Balıkesir University The Journal of Social Sciences Institute, 22(42), pp.175-194. Available at: https://doi.org/10.31795/baunsobed.657002.

Badi, I. \& Ballem, M. 2018. Supplier selection using the rough BWM MAIRCA model: A case study in pharmaceutical supplying in Libya. Decision Making: Applications in Management and Engineering, 1(2), pp.16-33 [online]. Available at: https://www.dmame.rabek.org/index.php/dmame/article/view/12 [Accessed: 1 May 2021].

Belbag, S., Deveci, M. \& Uludag, A.S. 2013. Comparison of two fuzzy multi criteria decision methods for potential airport location selection. In: Proceedings of the 2nd International Conference on Operations Research and Enterprise Systems - ICORES,Barcelona, pp.270-276. Available at: https://doi.org/10.5220/0004279702700276.

Bobar, Z., Božanić, D., Djurić, K.A. \& Pamučar, D. 2020. Ranking and Assessment of the Efficieny of Social Media using the Fuzzy AHP-Z Number Model - Fuzzy MABAC. Acta Polytechnica Hungarica, 17(3), pp.43-70 [online]. Available at: http://acta.uni-obuda.hu/Bobar_Bozanic_Djuric_Pamucar_100.pdf [Accessed: 1 May 2021]. 
Božanić, D., Jurišić, D. \& Erkić, D. 2020a. LBWA - Z-MAIRCA model supporting decision making in the army. Operational Research in Engineering Sciences: Theory and Applications, 3(2), pp.87-110 [online]. Available at: https://www.oresta.rabek.org/index.php/oresta/article/view/60 [Accessed: 1 May 2021].

Božanić, D., Pamučar, D. \& Tešić, D. 2019a. Selection of the location for construction, reconstruction and repair of flood defense facilities by IR-MAIRCA model application. In: Proceedings of the 5th International Scientific-Professional Conference Security and Crisis Management - Theory and Practice (SeCMan), Belgrade, pp.276-284, October 3-4 [online]. Available at: https://bekmen.rs/zbornik/2019/2019-Zbornik-ENG.pdf [Accessed: 1 May 2021]. ISBN: 978-86-80692-04-3.

Božanić, D., Tešić, D. \& Kočić, J. 2019b. Multi-criteria FUCOM-fuzzy MABAC model for the selection of location for construction of single-span bailey bridge. Decision Making: Applications in Management and Engineering, 2(1), pp.132-146 [online]. Available at: https://www.dmame.rabek.org/index.php/dmame/article/view/32 [Accessed: 1 May 2021].

Božanić, D., Tešić, D. \& Milić, A. 2020b. Multicriteria decision making model with Z-numbers based on FUCOM and MABAC model. Decision Making: Applications in Management and Engineering, 3(2), pp.19-36 [online]. Available at: https://dmame.rabek.org/index.php/dmame/article/view/72 [Accessed: 1 May 2021].

Božanić, D.I. \& Pamučar, D.S. 2010. Evaluating locations for river crossing using fuzzy logic. Vojnotehnički glasnik/Military Technical Courier, 58(1), pp.129145. Available at:https://doi.org/10.5937/vojtehg1001129B.

Božanić, D.I., Pamučar, D.S. \& Karović, S.M. 2016b. Application of MABAC multi-criteria method to support decision making process of a force deployment in defense operation. Tehnika, 71(1), pp.129-136 (in Serbian). Available at: https://doi.org/10.5937/tehnika1601129B.

Božanić, D.I., Pamučar, D.S. \& Karović, S.M. 2016a. Use of the fuzzy AHP MABAC hybrid model in ranking potential locations for preparing laying-up positions. Vojnotehnički glasnik/Military Technical Courier, 64(3), pp.705-729. Available at: https://doi.org/10.5937/vojtehg64-9261.

Chou, Y-C, Yen, H-Y, Dang, V.T. \& Sun, C-C. 2019. Assessing the Human Resource in Science and Technology for Asian Countries: Application of Fuzzy AHP and Fuzzy TOPSIS. Symmetry, 11(2), art.number:251. Available at:https://doi.org/10.3390/sym11020251.

Demirel, N.Ç., Deveci, M. \& Eser, G. 2016. Comparative analysis of fuzzy multi-criteria decision making for location selection of Textile plant in Turkey. In: Proceedings of the 24th International Academic Conference, Barcelona, art.number:4006524, August [online]. Available at: https://ideas.repec.org/p/sek/iacpro/4006524.html [Accessed: 1 May 2021]. 
Deveci, M., Erdogan, N., Cali, U., Stekli, J. \& Zhong, S. 2021. Type-2 neutrosophic number based multi-attributive border approximation area comparison (MABAC) approach for offshore wind farm site selection in USA. Engineering Applications of Artificial Intelligence, 103, art.number:104311. Available at: https://doi.org/10.1016/j.engappai.2021.104311.

Deveci, M., Kuvvetli, Y. \& Akyurt, I.Z. 2020a. Survey On Military Operations Of Fuzzy Set Theory And Its Applications. Journal of Naval Sciences and Engineering, 16(2), pp.117-141 [online]. Available at: https://dergipark.org.tr/en/pub/jnse/issue/57757/781815 [Accessed: 1 May 2021].

Deveci, M., Özcan, E. \& John, R. 2020b. Offshore Wind Farms: A Fuzzy Approach to Site Selection in a Black Sea Region. In: IEEE Texas Power and Energy Conference (TPEC), College Station, TX, USA, pp.1-6, February 1-6. Available at: https://doi.org/10.1109/TPEC48276.2020.9042530.

Di Matteo, U., Pezzimenti, P.M. \& Garcia, D.A. 2016. Methodological Proposal for Optimal Location of Emergency Operation Centers through MultiCriteria Approach. Sustainability, 8(1), art.number:50. Available at: https://doi.org/10.3390/su8010050.

Gigović, Lj., Pamučar, D., Božanić, D.\& Ljubojević, S.2017. Application of the GIS-DANP-MABAC multi-criteria model for selecting the location of wind farms: A case study of Vojvodina, Serbia. Renewable Energy, 103, pp.501-521. Available at: https://doi.org/10.1016/j.renene.2016.11.057.

-Military-Today. 2021. Malyutka, Anti-tank guided missile [online]. Available athttp://www.military-today.com/missiles/malyutka.htm [Accessed: 1 May 2021].

Milosavljević, M., Bursać, M. \& Tričković, G. 2018. Selection of the railroad container terminal in Serbia based on multi criteria decision-making methods. Decision Making: Applications in Management and Engineering, 1(2), pp.1-15 [online].

Available

at: https://www.dmame.rabek.org/index.php/dmame/article/view/11 [Accessed: 1 May 2021].

Muhammad, L.J., Badi, I., Haruna, A.A., \& Mohammed, I.A. 2021. Selecting the Best Municipal Solid Waste Management Techniques in Nigeria Using Multi Criteria Decision Making Techniques. Reports in Mechanical Engineering, 2(1), pp.180-189. Available at: https://doi.org/10.31181/rme2001021801b.

Pamucar, D., Deveci, M., Canitez, F. \& Lukovac, V. 2020. Selecting an airport ground access mode using novel fuzzy LBWA-WASPAS-H decision making model. Engineering Applications of Artificial Intelligence, 93, art.number:103703. Available

https://doi.org/10.1016/j.engappai.2020.103703.

Pamucar, D.S., Pejcic Tarle, S. \& Parezanovic, T. 2018b. New hybrid multicriteria decision-making DEMATEL-MAIRCA model: sustainable selection of a location for the development of multimodal logistics centre. Economic researchEkonomska istraživanja, 31(1), pp.1641-1665. Available at: https://doi.org/10.1080/1331677X.2018.1506706. 
Pamučar, D. \& Ćirović, G. 2015. The selection of transport and handling resources in logistics centers using Multi-Attributive Border Approximation area Comparison (MABAC). Expert Systems with Applications, 42(6), pp.3016-3028. Available at: https://doi.org/10.1016/j.eswa.2014.11.057.

Pamučar, D., Lukovac, V., Božanić, D. \& Komazec, N. 2018a. Multi-criteria FUCOM-MAIRCA model for the evaluation of level crossings: case study in the Republic of Serbia. Operational Research in Engineering Sciences: Theory and Applications, 1(1), pp.108-129 [online]. Available at: https://oresta.rabek.org/index.php/oresta/article/view/10 [Accessed: 1 May 2021].

Pamučar, D., Sremac, S., Stevic, Ž., Ćirović, G. \& Tomić, D. 2019. New multicriteria LNN WASPAS model for evaluating the work of advisors in the transport of hazardous goods. Neural Computing and Applications, 31, pp.5045-5068. Available at: https://doi.org/10.1007/s00521-018-03997-7.

Pamučar, D.S. \& Savin, L.M. 2020. Multiple-criteria model for optimal offroad vehicle selection for passenger transportation: BWM-COPRAS model. Vojnotehnički glasnik/Military Technical Courier, 68(1), pp.28-64. Available at: https://doi.org/10.5937/vojtehg68-22916.

Pamučar, D.S., Božanić, D.I. \& Kurtov, D.V. 2016. Fuzzification of the Saaty's scale and a presentation of the hybrid fuzzy AHP-TOPSIS model: an example of the support decision making process of a force deployment in defense operation. Vojnotehnički glasnik/Military Technical Courier, 64(4) pp.966-986. Available at: https://doi.org/10.5937/vojtehg64-9262.

МНОГОКРИТЕРИАЛЬНАЯ МОДЕЛЬ ОПТИМИЗАЦИИ ЗАКУПОК ПРОТИВОТАНКОВЫХ КОМПЛЕКСОВ

Драган С. Памучар ${ }^{\mathrm{a}}$, корреспондент, Слободан Р. Димитриевичб

а Университет обороны в г. Белград, Военная академия,

Кафедра логистики, г. Белград, Республика Сербия

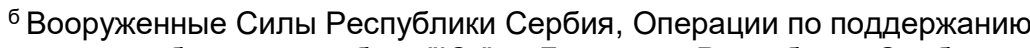

мира, учебный центр, база "Юг", г. Буяновац, Республика Сербия

РУБРИКА ГРНТИ: 27.00.00 МАТЕМАТИКА:

27.47.19 Исследование операций,

28.00.00 КИБЕРНЕТИКА:

28.17.31 Моделирование процессов управления,

78.00.00 ВОЕННОЕ ДЕЛО:

78.25.00 Вооружение и военная техника

ВИД СТАТЬИ: оригинальная научная статья

Резюме:

Введение/цель: Противотанковые управляемые ракеты (ПТУР) представляют собой один из самых эффрективных комплексов вооружения для противодействия бронетанковым и механизированным войскам. Вооружение данным видом техники 
является преимущественным для вооруженных сил любой страны. Соответствующая оценка и выбор эфрфективных комплексов ПТУР - важнейший фактор, влияющий на оперативные возможности вооруженных сил. Цель данной статьи заключается $в$ представлении многокритериальных методов, являющимися полезным инструментом для решения проблемы оптимизации закупок ПТУР воореженными силами.

Методы: Ответственным лицам, принимающим решения по закупкам ПТУР предлагается внедрение многокритериальных мemoдов TOPSIS (Technique for Order Preference by Similarity to Ideal Solution - Meтод для выбора порядка предпочтения по сходству с идеальным решением) и MABAC (Мультиатрибутивная мдоель сравнения граничных аппроксимативных областей). В данной статье представлены возможные решения по четырем моделям ПТУР. Описанные ПТУР представлены как варианты A1, A2, A3 и A4.

Результаты: На основании методов, описанных в данной статье, можно сделать вывод, что самым благоприятным является вариант A2, а соответственно и лучшим решением при выборе ответствтвенными лицами, принимающими решения касательно закупок данной модели ПТУР.

Выводы: Приходим к выводу, что математические модели многокритериальных методов принятия решений, представленные в данной статье, недвусмысленно указывают на альтернативу с лучшими характеристиками и представляют собой выигрышный и чрезвычайно удобный инструмент для ответственных лиц, принимающих решения.

Ключевые слова: TOPSIS, MABAC, закупка систем вооружения, многокритериальное принятие решений.

\section{ИЗБОР ПРОТИВОКЛОПНИХ ВОЪЕНИХ РАКЕТА МОДЕЛОМ ВИШЕКРИТЕРИЈУМСКОГ ОДЛУЧИВАҢА}

Драган С. Памучар ${ }^{a}$, аутор за преписку,Слободан Р. Димитријевићб

а Универзитет одбране у Београду, Војна академија,

Катедра логистике, Београд, Република Србија

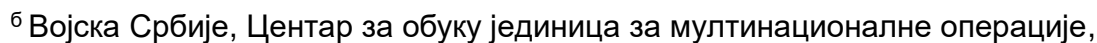
база „Југ”, Бујановац, Република Србија

ОБЛАСТ: математика, логистика

ВРСТА ЧЛАНКА: оригинални научни рад

Сажетак:

Увод: Противоклопне вођене ракете (ПОВР) представљају једно од најефрикаснијих оруђа у супротстављању оклопним $u$ 
механизованим јединицама. Опремање овим оруђима представља императив оружаних снага било које државе. Адекватна евалуација и избор ефикасних ПОВР представља важан фрактор који утиче на оперативне способности оружаних снага. Циљ овог рада јесте да прикаже да методе вишекритеријумског одлучивања представљају користан алат за решавање проблема оптималне набавке ПОВР за оружане снаге.

Meтоде: Имплементација TOPSIS (Technique for Order Preference by Similarity to Ideal Solution - техника за одабир наручбине по сличности са идеалним решењем) и МABAC (Multi Attributive Border Approximation Area Comparison - вишеатрибутивно упоређивање граничних апроксимативних области) метода биће предложене за доносиоче одлука за решавање проблема набавке ПОВР. У раду су предложене четири врсте ПОВР као могућа решења. Наведене ПОВР приказане су као алтернативе A1, A2, АЗ и A4.

Резултати: Имплементација метода довела је до закључка да алтернатива А2 има највишу вредност и да представља најбољи избор који доносиоци одлука могу донети за избор ове врсте ПОВР.

Закључак: Математички модели вишекритеријумског одлучивања, примењени у овом раду, недвосмислено указују на алтернативу са најбољим карактеристикама, па представљају захвалан и изузетно користан алат за доносиоце одлука.

Кључне речи: TOPSIS, MABAC, набака оружаних система, вишекритеријумско одлучивање.

Paper received on / Дата получения работы / Датум пријема чланка: 05.05.2021. Manuscript corrections submitted on / Дата получения исправленной версии работы / Датум достављања исправки рукописа: 16.10.2021.

Paper accepted for publishing on / Дата окончательного согласования работы / Датум коначног прихватања чланка за објављивање: 18.10.2021.

(c) 2021 The Authors. Published by Vojnotehnički glasnik / Military Technical Courier (www.vtg.mod.gov.rs, втг.мо.упр.срб). This article is an open access article distributed under the terms and conditions of the Creative Commons Attribution license (http://creativecommons.org/licenses/by/3.0/rs/).

(c) 2021 Авторы. Опубликовано в «Военно-технический вестник / Vojnotehnički glasnik / Military Technical Courier» (www.vtg.mod.gov.rs, втг.мо.упр.срб). Данная статья в открытом доступе и распространяется в соответствии с лицензией «Creative Commons» (http://creativecommons.org/licenses/by/3.0/rs/).

() 2021 Аутори. Објавио Војнотехнички гласник / Vojnotehnički glasnik / Military Technical Courier (www.vtg.mod.gov.rs, втг.мо.упр.срб). Ово је чланак отвореног приступа и дистрибуира се у складу са Creative Commons лиценцом (http://creativecommons.org/licenses/by/3.0/rs/).

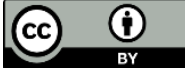

